\begin{tabular}{|c|l|}
\hline Title & Shell-Exchange Behavior in a Hermit-Crab-Like Tanaidacean (Crustacea: Malacostraca) \\
\hline Author(s) & Kakui, Keiichi \\
\hline Citation & $\begin{array}{l}\text { Zoological Science, 36(6), 468-470 } \\
\text { https://doi.org/40.2108/2s190048 }\end{array}$ \\
\hline Issue Date & 2019-12 \\
\hline Doc URL & http://hdl.handle.net/2115/79859 \\
\hline Type & article \\
\hline File Information & Zool Sci 36_468_470.pdf \\
\hline
\end{tabular}

Instructions for use 


\title{
Shell-Exchange Behavior in a Hermit-Crab-Like Tanaidacean (Crustacea: Malacostraca)
}

\author{
Keiichi Kakui* \\ Faculty of Science, Hokkaido University, Sapporo 060-0810, Japan
}

\begin{abstract}
This study describes shell-exchange behavior in the hermit-crab-like tanaidacean Macrolabrum sp. (Pagurapseudidae: Pagurapseudinae) under captive conditions. I observed one shell exchange by Macrolabrum sp., the behavioral sequence of which was as follows: a shell-carrying tanaidacean 1) grasped the edge of the aperture of an empty gastropod shell with its right cheliped; 2) inspected the condition inside the shell four times by inserting the anterior portion of its body into the shell; and 3) moved into the shell, posterior end (pleotelson) first. The elapsed time from the initial grasping of the empty shell to completing the move into it was $2 \mathrm{~min} 20 \mathrm{sec}$. In contrast to a Pagurapseudes tanaidacean and hermit crabs, the individual of Macrolabrum sp. did not examine the external surface of the shell during the single shell exchange observed.
\end{abstract}

Key words: conchicolous lifestyle, asymmetry, mobile shelter, convergence, evolution, Arthropoda, Peracarida

\section{INTRODUCTION}

Empty gastropod shells are abundant and ubiquitous in aquatic environments and are utilized for shelter or brooding by species in various animal groups, including fishes (Sato and Gashagaza, 1997), octopuses (Anderson, 1997), peanut worms (Ferrero-Vicente et al., 2013), polychaetes (Petersen, 2000), and crustaceans (Carter, 1982). Among shell users, the conchicolous anomuran decapods commonly called hermit crabs use gastropod shells as mobile shelters and show striking morphological adaptations for shell use, including a twisted abdomen, anterior pereopods far longer than succeeding pereopods, and shell-gripping structures on some appendages (Tudge et al., 2012; Bird and Webber, 2015; McLaughlin, 2015).

Remarkable morphological adaptations for shell use are also found in the crustacean order Tanaidacea. Although most tanaidaceans have symmetrical, cylindrical bodies and inhabit the sea floor, members of Pagurapseudinae Lang, 1970 show specialized morphological features such as those above and utilize empty gastropod shells as mobile shelters, similarly to hermit crabs (Larsen et al., 2015; Kakui, 2016). As Tanaidacea and Decapoda are phylogenetically distant at the superorder level (Peracarida vs. Eucarida; both are in Malacostraca), and shell-carrying members occupy a derived phylogenetic position within each group (Kakui et al., 2011; Wolfe et al., 2019), their hermit-crab-like features must have resulted from convergent evolution. Thus, Tanaidacea provides another model for studying how descendants from a symmetrical-bodied ancestor underwent remarkable morphological evolutionary changes for the conchicolous mode of life, and what associated physio-

\footnotetext{
* Corresponding author. E-mail: kakui@eis.hokudai.ac.jp doi:10.2108/zs190048
}

logical, neural, and behavioral modifications are essential for this mode of life in Malacostraca.

Pagurapseudine tanaidaceans are generally less than $3.5 \mathrm{~mm}$ in total length, similar in size to hermit-crab glaucothoes (Bird and Webber, 2015). They are relatively well studied morphologically (e.g., Whitelegge, 1901; Messing, 1979; Bird and Webber, 2015), but the behavioral aspects of their shell use have been poorly described. Like hermit crabs, they exchange shells as they grow, but among 31 species in three genera (Bird and Webber, 2015), shell exchange has been described only in Pagurapseudes largoensis McSweeny, 1982, without images (Messing, 1979). Here I describe shell-exchange behavior in an unidentified pagurapseudine species in the genus Macrolabrum, using sequential images.

\section{MATERIALS AND METHODS}

One Macrolabrum sp. individual in a gastropod shell ("old shell"; Rissoidae sp.) was collected from the green alga Boodlea coacta in the intertidal zone at Bise, Okinawa, Japan $\left(26^{\circ} 42^{\prime} 41.2^{\prime \prime} \mathrm{N}\right.$ $127^{\circ} 52^{\prime} 45.3^{\prime \prime} \mathrm{E}$ ) on 2 August 2008 (all geographical coordinates were obtained from Google Earth Pro Ver. 7.3 [Google, 2019]); the individual was unfortunately lost after video recording. An empty gastropod shell ("new shell"; Barleeiidae sp.), which has greater shell height and wider aperture than the old shell, was collected in the intertidal zone at Oshoro, Hokkaido, Japan (4312'39.6"N $\left.140^{\circ} 51^{\prime} 25.6^{\prime \prime} \mathrm{E}\right)$. The tanaidacean was maintained in the laboratory, in seawater in a Petri dish with a piece of Kimtowel wipe (Nippon Paper Crecia, Japan) covering the bottom, at room temperature and under ambient light. To record behavior, the new shell and the animal along with its old shell were transferred by pipette to another Petri dish under the same condition; video recording was carried out with an Optio W60 digital camera (Pentax, Japan) attached to a stereomicroscope. Still images were extracted from the recorded video with a VLC media player (VideoLAN, France) and trimmed with Photoshop CS6 (Adobe, USA). 


\section{RESULTS AND DISCUSSION}

I observed a single shell exchange by Macrolabrum sp., which entailed the following behavioral sequence (Fig. 1). i) The shellcarrying animal (Fig. 1A) grasped the edge of the aperture of the new shell with its right cheliped (Fig. 1B). ii) It examined the inside of the new shell by inserting the anterior portion of its body into the shell (Fig. 1C-F), with the posterior portion of the body remaining in the old shell; this examination sequence was repeated four times in total. iii) The animal curled its body ventrally and started to insert it into the new shell, posterior end (pleotelson) first (Fig. 1G-H). iv) The animal released the old shell (Fig. 1I). v) The animal retracted its entire body deeply into the new shell one time (Fig. 1J). vi) It resumed walking (Fig. 1K). The elapsed time from Fig. 1B to Fig. 11 was 2 min $20 \mathrm{sec}$. The video recording of this shell exchange has been deposited in the figshare repository (Kakui, 2019).

In investigating the behavior of a tanaidacean obtaining or exchanging shells, Messing (1979) utilized individuals of Pagurapseudes largoensis with and without shells (Messing referred to his study animal as "Pagurapseudes sp."; McSweeny [1982] later described it as new). In short, $P$. largoensis first checked the condition of the empty shell outside and inside with its chelipeds and pereopods, and then entered the empty shell by inserting its body, posterior end (pleotelson) first. The behavioral sequence that Messing reported was similar to that which I observed for Macrolabrum sp., and is the same behavioral sequence that hermit crabs use in shell exchange (Reese, 1963; McLaughlin, 2015). The shell-exchange behavior I observed in Macrolabrum sp. differed slightly from that reported in Pagurapseudes and hermit crabs, in that Macrolabrum sp. did not examine the external surface of the shell. However, as I observed only one shell exchange, it is unknown whether Macrolabrum sp. consistently inspects only the inside of the shell, but not the outside; this aspect of the behavior may vary among individuals and/or trials.

This is the first study describing shell-exchange behavior in a pagurapseudine tanaidacean by using sequential images. Hermit crabs show many other relatively well studied, shell related behaviors such as shell fighting and shell selection (Reese, 1962; Elwood and Briffa, 2001) that have been less well studied in pagurapseudine tanaidaceans. Future research on both morphology and behavior in
Pagurapseudinae will contribute significantly to elucidating which features are general and which are group-specific in the evolution of the shell-inhabiting lifestyle in malacostracan crustaceans.

\section{ACKNOWLEDGMENTS}

I thank Shoichi Kimura for help with identification of gastropod shells; Kazuhiro Kogame for identification of algae; Yoshikatsu Nakano for information on the sampling site; and Matthew H. Dick for reviewing the manuscript and editing the English.

\section{COMPETING INTERESTS}

The author declares that he has no competing interests.

\section{AUTHOR CONTRIBUTIONS}

KK collected and reared the animal, observed and recorded behavior, and wrote the manuscript.

\section{REFERENCES}

Anderson TJ (1997) Habitat selection and shelter use by Octopus tetricus. Mar Ecol Prog Ser 150: 137-148

Bird GJ, Webber R (2015) The first pagurapseudid species (Peracarida: Tanaidacea) from New Zealand with remarks on 
paguridean (Decapoda: Paguridea) and pagurapseudid convergence and competition. Zootaxa 3995: 149-168

Carter JW (1982) Natural history observations on the gastropod shell-using amphipod Photis conchicola Alderman, 1936. J Crustacean Biol 2: 328-341

Elwood RW, Briffa M (2001) Information gathering and communication during agonistic encounters: a case study of hermit crabs. Adv Stud Behav 30: 53-97

Ferrero-Vincente LM, Marco-Méndez C, Loya-Fernández Á, Sánchez-Lizaso JL (2013) Limiting factors on the distribution of shell/tube-dwelling sipunculans. J Exp Mar Bio Ecol 446: 345354

Google (2019) Google Earth Pro Ver. 7.3, available at http://www. google.com/earth/

Kakui K (2016) Review of the taxonomy, diversity, ecology, and other biological aspects of Order Tanaidacea from Japan and surrounding waters. In "Species Diversity of Animals in Japan" Ed by M Motokawa, H Kajihara, Springer, Japan, pp 603-627

Kakui K (2019) Shell exchange in the hermit-crab-like tanaidacean, Macrolabrum sp. figshare, available at https://doi.org/10.6084/ m9.figshare.7916288

Kakui K, Katoh T, Hiruta SF, Kobayashi N, Kajihara H (2011) Molecular systematics of Tanaidacea (Crustacea: Peracarida) based on $18 \mathrm{~S}$ sequence data, with an amendment of suborder/ superfamily-level classification. Zool Sci 28: 749-757

Larsen K, Guţu M, Sieg J (2015) Order Tanaidacea Dana, 1849. In "The Crustacea. Revised and Updated, as well as Extended from the Traité de Zoologie 5" Ed by JC von Vaupel Klein, M Charmantier-Daures, FR Schram, Brill, Leiden, pp 249-329

McLaughlin PA (2015) Crustaceans in mobile homes. In "The Natural History of the Crustacea vol. 2. Lifestyles and Feeding Biology" Ed by M Thiel, L Watling, Oxford University Press,
New York, pp 145-162

McSweeny ES (1982) A new Pagurapseudes (Crustacea: Tanaidacea) from southern Florida. Bull Mar Sci 32: 455-466

Messing CG (1979) Pagurapseudes (Crustacea: Tanaidacea) in southeastern Florida: functional morphology, post-marsupial development, ecology and shell use. Doctoral dissertation, University of Miami, Florida

Petersen ME (2000) A new genus of Fauveliopsidae (Annelida: Polychaeta) with a review of its species and description of some described taxa. Bull Mar Sci 57: 491-515

Reese ES (1962) Shell selection behavior of hermit crabs. Anim Behav 10: 347-360

Reese ES (1963) The behavioral mechanisms underlying shell selection by hermit crabs. Behaviour 21: 78-124

Sato T, Gashagaza MM (1997) Shell-brooding cichlid fishes of Lake Tanganyika: their habitats and mating systems. In "Fish Communities in Lake Tanganyika" Ed by H Kawanabe, M Hori, M Nagoshi, Kyoto University Press, Kyoto, pp 221-240

Tudge CC, Asakura A, Ahyong ST (2012) Infraorder Anomura MacLeay, 1838. In "The Crustacea. Revised and Updated, as well as Extended from the Traité de Zoologie 9 Part B" Ed by FR Schram, JC von Vaupel Klein, Brill, Leiden, pp 221-333

Whitelegge T (1901) Scientific results of the trawling expedition of H.M.C.S. "Thetis," off the coast of New South Wales, in February and March, 1898, Part 2. Crustacea. Part II. Isopoda. Part I. Aust Mus Mem 4: 203-246

Wolfe JM, Breinholt JW, Crandall KA, Lemmon AR, Lemmon EM, Tim LE, et al. (2019) A phylogenomic framework, evolutionary timeline and genomic resources for comparative studies of decapod crustaceans. Proc R Soc B 286: 20190079

(Received April 5, 2019 / Accepted May 22, 2019) 